УДК $342.72 / .73$

DOI https://doi.org/10.32849/2663-5313/2020.4.38

Ірина Сторожук,

канд. юрид. наук, дочент,

доцент кафедри конституційного, адміністративного та фінансового права

Хмельнииького університету управління та права імені Леоніда Юзькова

Валентина Кізляр,

аспірант кафедри конституиійного, адміністративного та фінансового права

Хмельницького університету управління та права імені Леоніда Юзькова

\title{
ПРАВОВА ПРИРОДА ПОНЯТТЯ «ІНФОРМАЦІЙНІ ПРАВА» ТА ЙОГО ЗНАЧЕННЯ
}

Стаття присвячена аналізу суті конституиійної категорії «інформаиійні права». Більшість досліджень стосовно інформаційних конституційних прав присвячені лише праву на інформацію як конституиійне право громадянина та право на доступ до публічної інформачії, залишаючи поза увагою норми, що визначають функиії держави чи компетенцію публічних органів держави у сфері обігу інформаиії. Вважаємо, шо до конституиійних основ інформаиійного законодавства потрібно віднести також права й свободи людини та громадянина як у сфері обміну інформачії, так $і$ компетениії окремих органів щодо забезпечення інформачійних прав, а також їх захист. Інформаиійні права - ие конститучійні права й свободи людини в різних сферах, на які значною мірою впливає розвиток інформачійно-комунікаиійних технологій в інформачійному суспільстві. Якщо розглядати термін «інформачійні права» з точки зору конституиійного закріплення, то складовими його будуть як саме право на інформачію, так і низка прав, свобод людини й громадянина, об'єктом яких є інформація, інформащійні ресурси, інформаційні послуги та інще. Отже, інформаційні права можна умовно поділити на основне право, об'єктом якого є безпосередньо інформачія, тобто право на інформачію, i дотичні - че права, реалізачія яких пов'язана з інформаційною складовою. До дотичних відносимо право на таємниию листування, телефонних розмов, телеграфної та іншої кореспондениії, право на свободу світогляду й віросповідання та інші.

Хоча иифрові права (як доступ до Інтернету) офіиійно не визнанні як права людини, але їх треба розглядати як умову для реалізачії права на свободу думки й слова, на вільне висловлення своїх поглядів і переконань. Поняття «цифрові права» можна визначити як фундаментальні права людини, перенесені у віртуальний простір Інтернету.

Після визнання иифрових прав і свобод людини конституиійним правом вони посідатимуть місче серед основних інформачійних прав, тому що їхнім об'єктом також безпосередньо є інформація, тільки у віртуальній сфері.

Ключові слова: право на інформацію, право на доступ до інформації, права людини в інформаційній сфері, особисті права, культурні права, політичні права, цифрові права та свободи.

Постановка проблеми. В Україні останнім часом використання інформаційно-комунікаційних технологій стало невід'ємною частиною функціонування всіх сфер діяльності в суспільстві, а процеси інформатизації - пріоритетним напрямом державної політики. Складовою таких процесів є гарантування державою права на інформацію. Гарантування державою інформаційних прав можливе лише за умови, що це правова й демократична держава. Тому що будь-які утиски демократії починаються з обмежень прав в інформаційній сфері. Такі інформаційні обмеження направлені насамперед на перешкоджання вільної можливості шукати, одержувати й поширювати інформацію за допомогою будь-яких засобів.

Конституція як Основний Закон держави рівнозначно впливає на всі суспільні відносини незалежно від сфери їхньої дії. Зважаючи на виняткову поширеність відносин, пов'язаних з інформацією в різних сферах життєдіяльності суспільства, вони не могли залишитися поза конституційним регулюванням.

Питання прав людини в умовах інформаційного суспільства, їх реалізації та безпосередньо право на інформацію досліджувались у роботах таких учених, як І.Л. Бачило, К.І. Бєляков, О.В. Кохановська, Н.В. Кушакова, 
B.А. Ліпкан, О.В. Малько, А.І. Марущак, О.В. Нестеренко, В.Ф. Погорілко, O.B. Скрипнюк, O.I. Ющик та інших.

Конституційне регулювання інформаційних відносин вивчали I.В. Арістова І.Л. Бачило, Г.В. Виноградова, Р.А. Калюжний, В.А. Копилов, Б.А. Кормич, І.С. Чиж та інші.

Метою статті є здійснення аналізу конституційних прав у сфері обігу інформації, які в сукупності формують конституційну категорію «інформаційні права».

Виклад основного матеріалу. На жаль, переважна більшість досліджень стосовно інформаційних конституційних прав присвячені вивченню лише права на інформацію як конституційного права громадянина або ж права на доступ до публічної інформації. Залишаються поза увагою норми, що визначають функції держави чи компетенцію публічних органів держави у сфері обігу інформації. Останні чинять не менший вплив на інформаційну сферу, а іноді й вагоміший, бо це дія держави чи вповноважених нею органів.

Саме тому, аналізуючи конституційні засади інформаційного законодавства 3 метою їх детальнішого дослідження, ми вважаємо за потрібне об'єднати в групи права щодо регулювання відносин в інформаційній сфері.

Б. Кормич, досліджуючи конституційні норми, спрямовані на регулювання інформаційних відносин, умовно поділяе їх на три групи: 1) норми, що встановлюють права й свободи людини у сфері інформації; 2) норми, які визначають особливості регулювання інформаційних відносин; 3) норми, що регулюють функції держави й компетенцію публічних органів держави в інформаційній сфері [1, с. 47]. Такий підхід $є$ найбільш прогресивним, однак вважаємо недоцільним виділення групи норм, що визначають особливості регулювання інформаційних відносин, в окрему групу конституційних норм у сфері інформації. Як зазначає В. Копилов, головною особливістю правового регулювання інформаційних відносин $€$ те, що його основу складають інформаційні права та свободи [2, с. 88]. Інформаційні відносини, як і інші відносини, структурно складаються з суб'єкта, об'єкта й змісту. Громадяни як фізичні особи, держава й публічні органи є суб'єктами таких правовідносин, а тому їхні права, свободи й повноваження $€$ складовою змісту інформаційних відносин. Виділення групи норм, що визначають особливості регулювання інформаційних відносин, є узагальнюючим і поглинальним поняттям стосовно двох інших груп.
Д. Огородов [3, с. 15-16] та О. Одінцова [4, с. 86], розглядаючи суб'єктивні інформаційні права в широкому розумінні, поділяють їх на абсолютні права на інформацію (право на особисту таємницю) й відносні (право на одержання інформації, право на поширення інформації). Такий підхід має право на існування, якщо розглядати інформаційні права загалом, однак у межах дослідження конституційних прав у сфері інформації вони охоплюють занадто вузький спектр інформаційних прав.

Вважаємо, що до конституційних основ інформаційного законодавства потрібно віднести й права та свободи як людини, так і громадянина як у сфері обміну інформації, так і компетенції окремих органів щодо забезпечення інформаційних прав, а також їх захист.

Тому пропонуємо конституційні норми, які $€$ основою інформаційного законодавства, умовно поділити на дві групи: 1) інформаційні права - це конституційні права та свободи людини в різних сферах, на які значною мірою впливає розвиток інформаційно-комунікаційних технологій в інформаційному суспільстві; 2) право на доступ до інформації - це конституційні норми, що встановлюють права у сфері обігу інформації відносно компетенції окремих органів публічної влади чи функцій держави.

У межах досліджуваної мети ми розглянемо лише категорію «інформаційні права».

Термін «інформаційні права» досить широко вживається в юридичній науці. I. Бачило, В. Лопатін, М. Федотов трактують інформаційні права як «основні права й свободи громадян, що реалізуються в інформаційній сфері» [5, с. 220].

Якщо розглядати термін «інформаційні права» 3 точки зору конституційного закріплення, то складовими його будуть як саме право на інформацію, так і ціла низка прав, свобод людини й громадянина, об’єктом яких є інформація, інформаційні ресурси, інформаційні послуги та інше. Отже, інформаційні права можна умовно поділити на основне (право, об'єктом якого є безпосередньо інформація, тобто право на інформацію) та дотичні (права, реалізація яких пов'язана з інформаційною складовою). До дотичних відносимо право на таємницю листування, телефонних розмов, телеграфної та іншої кореспонденції, право на свободу світогляду, віросповідання та інші.

Конституційні норми, що встановлюють інформаційні права та свободи людини, переважно містяться в розділі II Конституції України, що має назву «Права, свободи та обов'язки людини і громадянина». Основним $з$ них є право на інформацію. Вперше на міжнародному рівні право на інформацію 
було задекларовано в ст. 19 Загальної декларації прав людини, в якій записано, що «... кожна людина має право на свободу переконань і на вільне їх виявлення; це право включає свободу безперешкодно дотримуватися своїх переконань та свободу шукати, одержувати й поширювати інформацію та ідеї будь-якими засобами й незалежно від державних кордонів» [6]. Право на інформацію в Україні - це передбачене й гарантоване ч. 2 ст. 34 Конституції самостійне конституційне право, яке дозволяє людині вільно збирати, зберігати, використовувати й поширювати інформацію будь-яким способом.

Хоча право на інформацію було передбачено в Конституції одночасно з іншими правами, однак ставлення до його розуміння було неоднозначним. Якщо інші права беззаперечно було віднесено до певної категорії прав (особисті, культурні, політичні тощо), то право на інформацію донині не має однозначного місця в цій класифікації. Спочатку право на інформацію відносили до політичних прав (аргументом було те, що законодавець виписав його в одній статті з правом на свободу думки й слова, на вільне висловлення своїх поглядів і переконань). Однак право на інформацію набагато ширше, ніж політичне право, адже має багато інших проявів. Визнання його політичним правом $є$ наслідком ідеології та світогляду, що сформувалися за роки заполітизованого радянського режиму. Але право на самовираження, що передбачає також право на інформацію, є не тільки політичним правом громадянина, а й природним особистим правом, як право на життя, свободу пересування. Воно притаманне людині від народження, а не лише в контексті участі в політичному житті країни.

Деякі автори [7] зазначали, що віднесення цього права до політичних прав і свобод $\epsilon$ надмірною політизацією цієї свободи й відносили його до культурних (духовних) прав. Тому що інформація є невід'ємною складовою культурного чи духовного надбання певного соціуму й окремо людини. Така точка зору також має право на існування, адже право на інформацію можна віднести до культурних прав як можливість реалізувати свободу літературної, художньої, наукової чи технічної творчості (ст. 54 Конституції), право на освіту (ст. 53 Конституції) тощо. Очевидно, що реалізація соціальних та економічних прав неможлива без вільного поширення інформації. Ця думка підтверджується, зокрема, Декларацією свободи висловлювань та інформації [8], що була прийнята Комітетом міністрів Ради Європи у 1982 р. У ній наголошено, що свобода інформації необхідна для соціального, економічного, культурного й політичного розвитку кожної людини, вона є умовою гармонійного розвитку соціальних і культурних груп, націй і міжнародного співтовариства [9].

E також інша точка зору про місце права на інформацію в класифікації конституційних прав, а саме визнання цього права особистим правом кожного. Підтримуючи цей підхід вважаємо, що право на інформацію належить будь-якій людині 3 моменту народження незалежно від іiі громадянства й не може бути ніким скасовано чи припинено. Право на інформацію мають усі люди, що проживають на території нашої держави незалежно від їхнього правового статусу. Отже, право на інформацію завдяки своїй соціальній природі й набуттю за фактом народження однозначно належить до особистих прав людини.

Проведений аналіз показує, що в теорії конституційного права розуміння права на інформацію пройшло певний еволюційний шлях, який нині ще не завершений. Найбільшою трансформацією змісту інформаційних прав є виникнення такого феномену як «цифрові права та свободи».

П. Сухорольський $[10$, с. 21] у спеціальному дослідженні підкреслює, що в англомовних джерелах уже виділяються так звані цифрові права й свободи людини (digital rights and freedoms), під якими розуміють сукупність загальновизнаних та інших прав людини в контексті поширення нових цифрових технологій, зокрема Інтернету. Такий підхід дав підстави автору під інформаційними правами людини розуміти певний перелік основних прав людини в різних сфеpax, на які значною мірою впливає розвиток інформаційно-комунікаційних технологій в інформаційному суспільстві [11, с. 115].

Поняття «цифрові права» можна визначити як фундаментальні права людини, перенесені у віртуальний простір Інтернету. Рада Організації Об'єднаних Націй по правах людини прийняла резолюцію, відповідно до якої всі права людини з режиму офлайн рівною мірою повинні застосовуватись онлайн. Таким чином, Організація Об'єднаних Націй (далі - ООН) запропонувала не генерувати нові права для онлайн-простору, а розширити наявні, а саме: право на доступ, використання, створення й публікацію цифрових продуктів, а також доступ до комп'ютерів, електронних приладів і до мережі Інтернет [12].

Перехід прав з офлайн- в онлайн-режим чітко прослідковується в «Керівництві по правах людини для інтернет-користувачів» [13] Цей документ має рекомендаційний характер, однак у пояснювальному меморандумі до нього зазначено, що всі держави - члени Ради Свропи зобов'язані поважати, захищати 
й дотримуватися прав і свобод, що закріплені в ратифікованих ними документах. Зважаючи на те, що цей документ базується на Європейській конвенції захисту прав людини, він $€$ обов'язковим до виконання.

Натепер Інтернет є одним з основних засобів здійснення права на свободу думки та слова на вільне вираження своїх поглядів і переконань. Це право поширюється не лише на інформацію, а й на засоби її розповсюдження.

Спеціальний доповідач ООН з питання про право на свободу переконань і їх вільне вираження Франк Ларю підкреслив, що «Інтернет став необхідним інструментом для реалізації цілого спектра прав людини, боротьби з нерівністю й прискорення розвитку та людського прогресу, при цьому забезпечення загального доступу до Інтернету має бути пріоритетом для всіх держав. Кожна держава, виходячи $з$ цього, має розробляти конкретну й ефективну політику в консультаціях з людьми з усіх секторів суспільства у тому числі й з приватним сектором, і з відповідними державними установами, для того щоб Інтернет був широко доступний, відкритий і надавався за помірною вартістю для всіх груп населення.<...> Будучи каталізатором для людей у здійсненні їхнього права на свободу слова й висловлення думки, Інтернет дає змогу також реалізувати цілий спектр інших прав людини» [14].

Хоча цифрові права (як доступ до Інтернету) офіційно не визнанні як право людини, але їх треба розглядати як умову для реалізації права на свободу думки та слова, на вільне вираження своїх поглядів і переконань. Отже, ігнорування державою цифрових прав не тільки не виправдано, а й небезпечно, тому що швидкий розвиток глобальної інформаційної системи може призвести до неконтрольованості процесу дотримання прав людини у віртуальному просторі.

Тому вважаємо за потрібне внести доповнення до ст. 34 Конституції України, виклавши ч. 2 в такій редакції: «Стаття 34. Кожному гарантується право на свободу думки та слова, на вільне вираження своїх поглядів і переконань.

Кожен має право вільно збирати, зберігати, використовувати й поширювати інформацію усно, письмово або в інший спосіб на свій вибір. Кожній людині гарантовано иифрові права та свободи».

Потрібно зазначити, що визнання цифрових прав - процес неминучий, і питання тільки в строках. Або наша держава визнає цей вид прав і візьме на себе іх гарантування зараз, створивши базу для правового регламентування таких відносин. Або чекатиме настання масових порушень прав і свобод людини в неконтрольованій віртуальній сфері й буде змушена втрутитись і визнати існування цифрових прав і свобод як постфактум.

Після визнання цифрових прав і свобод людини конституційним правом вони займуть місце серед основних інформаційних прав, тому що їхнім об'єктом також безпосередньо $€$ інформація, тільки у віртуальній сфері.

До групи інформаційних прав, крім основного інформаційного права - права на інформацію, належать також дотичні інформаційні права, а саме: право на недоторканність особистого й сімейного життя, право на таємницю листування, телефонних розмов, телеграфної та іншої кореспонденції, право на повагу до гідності та честі та інші. Перелік інформаційних прав базується не стільки на наданні самого права, скільки на правовій забороні обмеження загального дозволу.

Прикладом такого дотичного інформаційного права $є$ ст. 28 Конституції [15], яка забороняє піддавати катуванню, жорстокому, нелюдському або такому, що принижує гідність, поводженню чи покаранню. Таке жорстоке поводження, що принижує людську гідність, усе частіше трапляється у віртуальному просторі, а саме в соціальних мережах. 3'явилася нова форма протиправної поведінки - кібербулінг, приниження за допомогою мобільних телефонів, Інтернету, інших електронних пристроїв. Л. Найдьонова розглядає кібербулінг як напади з метою завдання психологічної шкоди, які здійснюють через електронну пошту (e-mail), миттєві повідомлення (ICQ та інші системи), розгортаються в чатах, на вебсайтах, у соціальних мережах, через текстові повідомлення або зображення (фото, відео); до кібербулінгу належить також терор за допомогою мобільного телефонного зв'язку [16, с. 2]. Особлива небезпека кібербулінгу проявляється завдяки специфіці інтернет-середовища, а це анонімність, неможливість визначити кривдника, розповсюдження на широку аудиторію, тероризування жертви будь-де й будь-коли. Попри те, що такий вид правопорушень учиняється у віртуальному просторі, наслідки його проявляються в реальному житті, а саме в шкоді здоров'ю (зокрема психічному) чи навіть життю особи (у смерті чи доведенні до суїциду).

\section{Висновки}

Отже, аналіз конституційних основ інформаційних прав показав, що нині склалася така ситуація, що зміни в інформаційних відносинах вносять корективи в розуміння, розширюють зміст, а іноді й вимагають визнання нових інформаційних прав, що зафіксовані в Конституції та спонукають до розвитку нових напрямів державної політики в інформаційній сфері. 


\section{Список використаних джерел:}

1. Кормич Б. Конституційно-правове регулювання інформаційних відносин. Юридичний вісник. 2013. № 3. С. 46-51.

2. Копылов В.А. Информационное право. Москва, 2002. 512 с.

3. Огородов Д.В. Правовое регулирование отношений в информационной сфере : автореф. дис. ... канд. юр. наук. : спец. 12.00.03 «Гражданское право; предпринимательское право; семейное право; международное частное право» / Академия РАН. Москва, 2002. 21 с.

4. Одінцова О.О. Право на інформацію та реалізація інформаційних прав у сфері особистих немайнових прав людини в Україні. Вісник НТУу «КПI». Серія «Політологія. Соціологія. Право». Вип. 2 (18). 2013. С. 85-90.

5. Бачило И.Л., Лопатин В.Н., Федотов М.А. Информационное право : учебник. СанктПетербург. Юрид. центр Пресс, 2001. 725 с.

6. Загальна декларація прав людини : прийнята і проголошена резолюцією 217 А (III) Генеральної Асамблеї ООН від 10 грудня 1948 р. База даних «Законодавство України». URL: https://zakon.rada.gov.ua/laws/show/995 015.

7. Конституційне право України / за ред. В.Я. Тація та ін. Київ : Український центр правничих студій, 1999. 376 с.

8. Про свободу вираження поглядів та інформації : Декларація Комітету міністрів Ради Свропи від 29 квітня 1982 р. № 994 885. База даних «Законодавство Украӥни». URL: https://zakon.rada.gov.ua/ laws/show/994_885.

9. Кудрявцева С.П., Колос В.В. Міжнародна інформація : навчальний посібник. Київ :
Слово, 2005. 400 с. URL: https://buklib.net/books/ $22617 /$.

10. Сухорольський П. Проблеми забезпечення та розвитку прав людини в умовах інформаційного суспільства. Украӥнський часопис міжнародного права. 2013. № 1. С. 21.

11. Костецька Т.A. Конституційно-правове регулювання інформаційних прав: деякі термінологічні аспекти. Часопис Київського університету права. 2013. № 2. С.114-117.

12. Манучарян Д. Цифровые права. Есть ли они у украинцев? URL: https://lb.ua/ society/2017/11/24/382792_tsifrovie_prava li.html.

13. Руководство по правам человека для интернет-пользователей. Рекомендация СM $\operatorname{Rec}(2014) 6$, принятая Комитетом министров 16 апреля 2014 г., и пояснительный меморандум. URL: book.coe.int attachment.

14. Франк Ларю. Доклад по вопросу о праве на свободу убеждений и их свободное выражение. URL: http://www2.ohchr.org/english/bodies/ hrcouncil/docs/17session/a.hrc.17.27 en.pdf.

15. Конституція України : Закон України від 28 червня 1996 р. № 254к/96-ВР. Редакція від 1 січня 2020 р. URL: https://zakon.rada.gov.ua/ laws/show/254\%D0\%BA/96-\%D0\%B2\%D1\%80.

16. Найдьонова Л.А. Кібербулінг або агресія в Інтернеті: способи розпізнання і захист дитини : методичні рекомендації. Київ, 2011. 34 c. URL: https://docs.google.com/document/ d/1t7n0gp82 0ZAsgHCkCqAvGepLtc-4Wx18SIN v4 nbPMg/edit.

17. Калюжний К.Р. Сутність інформаційних прав людини в науці інформаційного права. Юридичний вісник. 2012. № 4 (25). С. 55-58.

The article is devoted to the analysis of the essence of the constitutional category "information rights". Most research on information constitutional rights is limited to the right to information as a constitutional right of a citizen and the right to the access to public information. Disregarding the rules defining the functions of the state or the competence of the public authorities of the state in the sphere of information circulation. We believe that the constitutional foundations of information law should include the rights and freedoms of the individual and the citizen, both in the sphere of information exchange and the competence of individual authorities in ensuring of the information rights, as well as their protection. Information rights are constitutional rights and freedoms of man in various fields, which are greatly influenced by the development of information and communication technologies in the information society. Considering the term information rights' from the point of view of constitutional consolidation, its composite element is the right to information as well as a whole range of rights, freedoms of a human and a citizen, the subject of which is information, information resources, information services and more. Consequently, information rights can be conditionally divided into a basic right whose object is information itself that is the right to information, and into related rights, namely the rights realization of which is related to the information component. These include the right to secrecy of correspondence, telephone conversations, telegraph and other correspondence, the right to freedom of opinion and religion, and others.

Although digital rights (like access to the Internet) are not officially recognized as human rights, they should be recognized as a condition for the exercise of the right to freedom of thought and speech, to the free expression of their viewes and beliefs. The term 'digital rights' can be defined as fundamental human rights transferred to the virtual space of the Internet.

After the recognition of digital rights and human freedoms as a constitutional right, they will take the place among fundamental information rights, because their object is also information itself only in the virtual sphere.

Key words: right to information, right to access to information, human rights in the information field, personal rights, cultural rights, political rights, digital rights and freedoms. 